\title{
Stock Status of Pufferfish Lagocephalus sceleratus (Gmelin, 1789) Along the Egyptian Coast, Eastern Mediterranean Sea
}

\author{
Mahmoud M. S. Farrag ${ }^{1, ~ *, ~ A l a a ~ E l d i n ~ A . ~ K . ~ E l-H a w e e t ~}{ }^{2}$, El-Sayed Kh. A. Akel ${ }^{3}$, \\ Mohsen A. Moustafa ${ }^{1}$ \\ ${ }^{1}$ Zoology Department, Faculty of Science, Al-Azhar University (Assiut Branch), Assiut, Egypt \\ ${ }^{2}$ College of Fisheries Technology and Aquaculture, Arab Academy for Science, Technology and Maritime Transportation, Alexandria, Egypt \\ ${ }^{3}$ Fisheries Division, National Institute of Oceanography \& Fisheries, Alexandria, Egypt
}

\author{
Email address: \\ m_mahrousfarrag@yahoo.com (M. M. S. Farrag), Mam_gene@yahoo.com (M. M. S. Farrag), \\ El_haweet@yahoo.com (A. E. A. K. Elhaweet), akeldraly@yahoo.com (El-Sayed Kh. A. Akel)
}

\section{To cite this article:}

Mahmoud M. S. Farrag, Alaa Eldin A. K. Elhaweet, El-Sayed Kh. A. Akel, Mohsen A. Moustafa. Stock Status of Puffer Fish Lagocephalus sceleratus (Gmelin, 1789) Along the Egyptian Coast, Eastern Mediterranean Sea. American Journal of Life Sciences. Special Issue: New Horizons in Basic and Applied Zoological Research. Vol. 3, No. 6-1, 2015, pp. 83-93. doi: 10.11648/j.ajls.s.2015030601.22

\begin{abstract}
Stock of pufferfish Lagocephalus sceleratus was evaluated using specimens that collected monthly from the commercial fishing boats at landing sites along whole the Egyptian Mediterranean coast during 2012. Specimens were ranged from 5 to $83 \mathrm{~cm}$ (TL) in length with an average $43.01 \pm 13.5 \mathrm{~cm}$ and total weight from $2.1-5400 \mathrm{~g}$ with an average of $1103.27 \pm 850.83 \mathrm{~g}$. The length-weight relationship revealed negative allometric growth for males, females and combined sexes with insignificant difference between males and females at $(\mathrm{P}>0.05)$. The highest condition factor (1. 13) was recorded for immature/smaller fishes while the lowest value 0.86 was recorded for largest female individual. Age determination by two methods (length frequency analysis and vertebrae) revealed seven years old with no significance difference between mean lengths at age of two methods at $(\mathrm{P}>0.05)$. Von Bertalanffy growth parameters for combined sexes of length frequency were L $\infty$ $=106.34 \mathrm{~cm}, \mathrm{~K}=0.17$ year $^{-1}$ and $\mathrm{t}_{\mathrm{o}}=0.0228$ year $^{-1}$, while they were $\mathrm{L} \infty=101.63 \mathrm{~cm}$ and $\mathrm{K}=0.189$ year $^{-1}$ and $\mathrm{t}_{\mathrm{o}}=0.1186$ for vertebrae data. By using data of length frequency, the population parameters were, total mortality $\left(\mathrm{Z}=1.01\right.$ year $\left.{ }^{-1}\right)$, natural mortality $\left(\mathrm{M}=0.347\right.$ year $\left.^{-1}\right)$, fishing mortality $(\mathrm{F}=0.663$ year $)$ and exploitation ratio $(\mathrm{E}=0.657)$. The length at first capture $(\mathrm{Lc})$ was $32.34 \mathrm{~cm}$, while length at recruitment $(\mathrm{Lr})$ was $25.95 \mathrm{~cm}$. Yield per recruit $(\mathrm{Y} / \mathrm{R})$ at current parameters was $447.26 \mathrm{~g}$. The

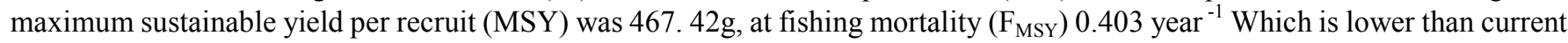
fishing mortality. The $(\mathrm{Y} / \mathrm{R})$ at the biological reference points $\left(\mathrm{F}_{0.1} \& \mathrm{~F}_{\max }\right)$ were $423.72 \mathrm{~g}$ and $467.42 \mathrm{~g}$ respectively. The fishing mortalities at these points were 0.203 year $^{-1}$ and 0.403 year $^{-1}$ for $F_{0.1}$ and Fmax respectively giving lower values than current fishing mortality reflecting over-exploitation status. Inspite of, the fishing of pufferfish is prohibited by the Egyptian law, its stock in the eastern Mediterranean is overexploited but still growing well and the younger individuals are in good condition reflecting a good adaptation in new habitat, and explain the illegal trade of this species in different markets. The over exploitation suggests reduce it or $\mathrm{Y} / \mathrm{R}$ to level of $\mathrm{F}_{0.1}$ for the point of conservation regardless its poisonous effect. The importance of present data of such species could emphasis the need of special management plan for conserve and better use of economically valuable fishery resources.
\end{abstract}

Keywords: Stock Status, L. sceleratus, Mediterranean Sea, Egypt

\section{Introduction}

Mediterranean Sea is considered as one of the main hotspots of marine bioinvasions on the earth, with an increase in rate of introduced invasives [1,2]. These invasives might have entered through several pathways as Suez Canal, Gibraltar Strait, ship ballast water and accidental release among others [3, 4]. Puffer fishes are among those invasives that attracted the attention since its migration to Mediterranean Sea with a rapid distribution along different countries of the basin and sound social impact. These fishes are belonging to Family Tetraodontidae which contains at least 187 species within the recognized 29 genera of Tetraodontidae [5].The silver stripe blaasop L. sceleratus [6] is 
considered a famous puffer fish species, it expanded its distribution widely from indopacific regions in tropical waters $[7,8]$ to different Mediterranean countries, including Turkish water as reported in $[9,10,11]$; Jaffa along the Israeli coast [12]; Rhodos as cited in [13,14]; Heraklion Bay, Cretan Sea [15]; from Lebanon coast by Carpentieri, et al., [16]; Aegean Sea, Greece [17, 18]; gulf of Gabes, Tunisia [19]. In the Egyptian Mediterranean waters, it was recorded in 2007 from Sallum Gulf, [20] and from Alexandria fish market in 2008 [21]; also it was recorded from Sicily [22, 23], from the Adriatic by [24]; from the coasts of Spain [25] after being recorded off the coast of Algeria by Kara et al. [26] and from Malta [27]. Due to its impacts results from the wide expansion of L. sceleratus, it becomes an ecological and economic issue which must be addressed, constantly studied and monitored as mentioned in [28, 29, 4].

Most of the scientific works that studied puffer fishes over the world were focused on its toxicity with little information about the biological aspects. Similar in Egypt, toxicology has got more intention particularly for Red Sea puffer fish species, while few studies had conducted some biological aspects as cited in [30]. For the Egyptian Mediterranean waters, one available study has studied fishery and biology of puffer fishes especially L. sceleratus as $\mathrm{Ph}$. D thesis. The present work is a part of that thesis and aimed to study age, growth and population parameters of the common lessepsian pufferfish Lagocephalus sceleratus as a basic knowledge for this species with evaluation of its stock status.

\section{Material and Methods}

\subsection{Study Area}

The present investigated area extended along the Egyptian Mediterranean coast from El-Arish eastward (34 $14^{\circ} 12^{\prime} 36^{\prime \prime} \mathrm{E}$ and $\left.31^{\circ} 15^{\prime} 00^{\prime \prime} \mathrm{N}\right)$ to El-Sallum westward $\left(25^{\circ} 08^{\prime} 42^{\prime \prime} \mathrm{E}\right.$ and $\left.31^{\circ} 30^{\prime} 00^{\prime \prime} \mathrm{N}\right)$. Specimens of L. sceleratus were collected monthly from landing sites and different commercial fishing boats that catch puffer fish along the whole Egyptian coast during the period from January to December 2012 (fig. 1).

\subsection{Age and Growth Parameters}

Length-weight relationship was calculated using 795 dissected specimens, based on power equation: $\mathrm{W}=\mathrm{a} \mathrm{L}^{\mathrm{b}}$ according to [31 Where $\mathrm{W}$ is the total weight in gram $(\mathrm{g}), \mathrm{L}$ is the total fish length in $\mathrm{cm}$; $a$ is the intercept and $b$ is the slope of the equation (exponent "b"), this exponent equal 3 for fishes means isometric growth and when the value of $(b)$ is higher or lower than 3 for fishes of allometric growth. Then the exponent "b" was tested statistically to determine whether the growth is allometric or isometric [32] Snedecor (1956). The condition factor $\left(\mathrm{K}=100 \mathrm{x}\right.$ Wgut $\left.\backslash \mathrm{L}^{3}\right)$ was calculated according to [33], where $\mathrm{W}_{\text {gut }}=$ Gutted weight in gram.

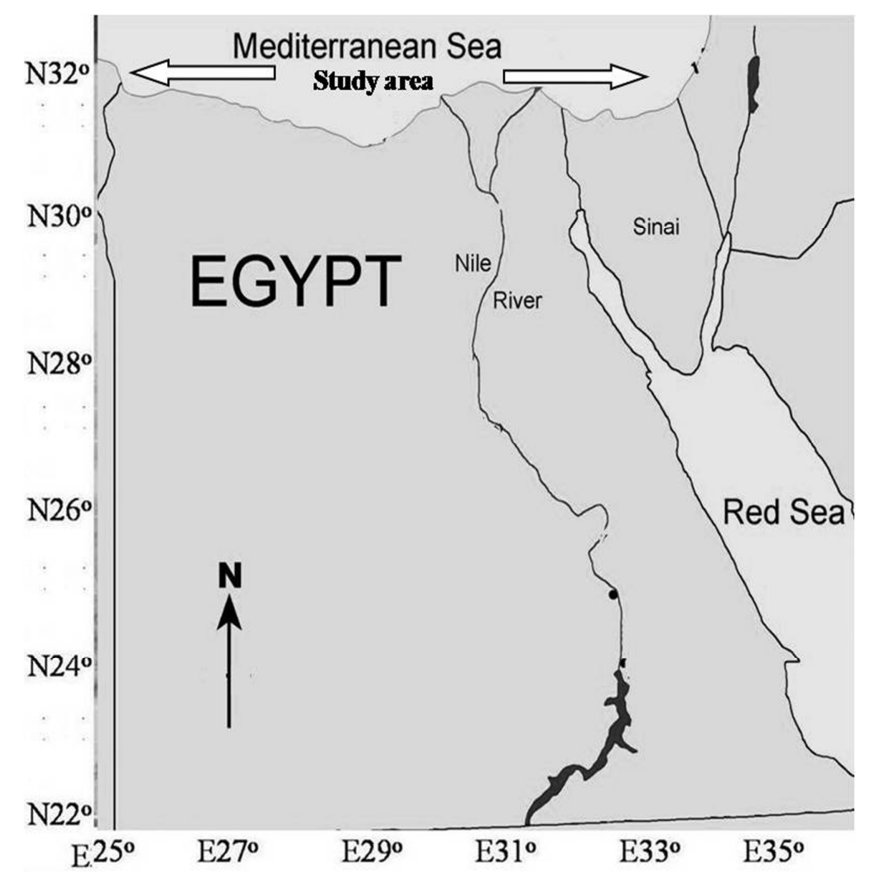

Figure 1. The study area along the Egyptian Mediterranean coast.

Age was determined by two methods, indirect by the analysis of length frequency distribution of [34], using subroutine of the Fi-SAT software as cited in [35]. The second method was direct by reading of the vertebrae. The trunk vertebrae No. 3 was carefully removed and placed in boiling distilled water for 2-3 minutes, cleaned from tissues, and stored dry. Age was determined by counting the opaque rings on the vertebral centrum. Sometimes, the whole vertebrae were not clear to be examined or read true rings, especially in small to moderate specimens. So, the concave centra of the vertebrae was cutting with a sharp knife into two sections, and placed dorsally up in a $\mathrm{V}$-shaped slit in a block and examined on a dark background with reflected light using binocular microscope at $(25 \mathrm{x})$ magnification.

Growth parameters ( $\mathrm{L}_{\infty}$ and $\mathrm{K}$ ) of Von Bertalanffy (VBGF) were estimated from the Length- at-age data subroutine in Fi-Sat II program for length frequency distribution data, while they were estimated according to [36, 37], for data of vertebrae.

The constant $\left(\mathrm{t}_{\mathrm{o}}\right)$ was calculated by rearranged formula of the von Bertalanffy equation: $\operatorname{Ln}\left[1-\left(\mathrm{L}_{\mathrm{t}} / \mathrm{L}_{\infty}\right)\right]=-\mathrm{k}^{*} \mathrm{t}_{\mathrm{o}}+\mathrm{k}^{*} \mathrm{t}$

The slope (b) of the previous straight line equation is equal to $(\mathrm{k})$ and the intercept (a) equal to $\left(-\mathrm{k}^{*} \mathrm{t}_{\mathrm{o}}\right)$ then: $\mathrm{t}_{\mathrm{o}}=-\mathrm{a} / \mathrm{b}$

Growth performance index $\left(\varnothing=\log \mathrm{k}+2 \log \mathrm{L}_{\infty}\right)$ was computed according to [38] Where: $\varnothing=$ growth performance Index.

\subsection{Population Parameters and Management}

The results of length frequency distribution method were used to estimate the population parameters. Total mortality $(Z)$ was estimated by the analysis of catch curve of [39] as $\mathrm{Ln} \mathrm{N}=$ $\mathrm{a}+\mathrm{b} * \mathrm{t}$ Where: $\mathrm{N}=$ Number of fishes in relative age group; $\mathrm{t}=$ relative age corresponding to the midpoint of the length class. The slope (b) is equal to (-Z). 
Natural mortality coefficient (M) was computed by equation of [40].

$\log M=-0.0066-0.2790 \log \mathrm{L}_{\infty}+0.6543 \log \mathrm{k}+0.4634$
$\log \mathrm{T}$

Where $\mathrm{T}$ is the annual mean water temperature of the

Egyptian Mediterranean water and was sit as $21.3 \mathrm{C}^{\circ}$ [41].

Fishing mortality coefficient $(\mathrm{F})$ was estimated as $\mathrm{F}=\mathrm{Z}-\mathrm{M}$ by [42].

Survival rate $(\mathrm{S})$ was computed from the following equation: $\mathrm{S}=\mathrm{e}^{-\mathrm{z}}[43]$.

Length at first capture $\left(\mathrm{L}_{\mathrm{c}}\right)$ was estimated as $\mathrm{L}_{\mathrm{c}}=\mathrm{L}^{-}-\mathrm{k}\left(\mathrm{L}_{\infty}\right.$ - $\mathrm{L}^{-}$) / $\mathrm{Z}$ according to [42]

where $\mathrm{L}^{-}$is the mean length of the catch. While its corresponding age $\left(t_{c}\right)$ obtained by using the von Bertalanffy growth equation $\left(\mathrm{t}_{\mathrm{c}}=-1 / \mathrm{K} \ln \left(1-\mathrm{L}_{\mathrm{c}} / \mathrm{L}_{\infty}\right)+\mathrm{t}_{\mathrm{o}}\right)$.

Length at recruitment $\left(\mathrm{L}_{\mathrm{r}}\right)$ was estimated as $\mathrm{L}_{\mathrm{r}}=\mathrm{L}^{-}-\mathrm{k}\left(\mathrm{L}_{\infty}-\right.$ $\left.L^{\prime}\right) / \mathrm{Z}$ according to [5], where $L^{\prime}$ is the length of fish at which fishes are under full recruitment (Cut off or the smallest length in the catch), and corresponding age $\left(t_{r}\right)$ was computed by the conversion of $\mathrm{L}_{\mathrm{r}}$ using (von Bertalanffy formula) $\mathrm{t}_{\mathrm{r}}=-1 / \mathrm{K} \ln$ $\left(1-\mathrm{L}_{\mathrm{r}} / \mathrm{L}_{\infty}\right)+\mathrm{t}_{\mathrm{o}}$

Exploitation ratio $(\mathrm{E})$ was calculated as $\mathrm{E}=\mathrm{F} / \mathrm{Z}$ according to [45].

The yield per recruit (Y/R) was estimated based on [42] that rearranged in [46] as follows:

$$
\begin{aligned}
\mathrm{Y} / \mathrm{R}=\mathrm{F} \mathrm{e}^{-\mathrm{M}(\mathrm{Tc}-\mathrm{Tr}) *} \mathrm{~W}_{\infty} * & {\left[(1 / \mathrm{Z})-(3 \mathrm{~S} / \mathrm{Z}+\mathrm{K})+\left(3 \mathrm{~S}^{2} / \mathrm{Z}+2 \mathrm{~K}\right)-\right.} \\
& \left.\left(\mathrm{S}^{3} / \mathrm{Z}+3 \mathrm{~K}\right)\right]
\end{aligned}
$$

Where: $\mathrm{S}=\mathrm{e}^{-\mathrm{k} \text { (Tc-to) }}, \mathrm{W}_{\infty}=$ asymptotic body weight that obtained through length weight relationship for converting $L_{\infty}$.

Biomass per recruit $(\mathrm{B} / \mathrm{R})$ model expresses the annual average biomass of survivors, it is estimated as following: $B / R$ $=(\mathrm{Y} / \mathrm{R}) / \mathrm{F}$ according to $[42]$

Biological reference points are precautionary reference points derived from the yield-per-recruit analyses. The most known points that estimated her include $F_{\max }$, the (fully-recruited or limit point) fishing mortality rate which produces the maximum yield per recruit; and $\mathrm{F}_{0.1}$ (target point) the fishing mortality rate corresponding to $10 \%$ of the slope of the yield-per-recruit curve at the origin [47], and computed using the following formula: $\mathrm{V}=\mathrm{Y} / \mathrm{R}-0.1 \mathrm{~B}_{0} \mathrm{~F}$ according to [48]

Where $\mathrm{V}$ is the function of yield at the obtained yield per recruit $(\mathrm{Y} / \mathrm{R}), \mathrm{B}_{0}$ is the virgin biomass per recruit (unexploited stock) when the value of fishing mortality equal zero, and " $F$ " is the fishing mortality at 0.1 . The results were treated statistically by using Microsoft Excel program, in addition to, one-way analysis of variance (ANOVA) test was conducted using STATISTICA (data analysis software system) version (8) [49].

\section{Results}

The length-weight relationship of Lagocephalus sceleratus was studied by using the 795 fish (408 males, 371 females and
16 unsexed). Samples were ranged between $5-83 \mathrm{~cm}$ (Total length) with an average of $43.01 \pm 13.5 \mathrm{~cm}$ and total weight from $2.1-5400 \mathrm{~g}$ with an average of $1103.27 \pm 850.83 \mathrm{~g}$ while the gutted weight ranged from 1.9-4890g with an average of $970.06 \pm 733.15 \mathrm{~g}$. The exponent "b" of the relationship equation was less than 3 showing negative allometric growth mode of males, females and C. sexes for both total and gutted weights as arranged below (Table 1).

Table 1. Length-weight relationship equations for males, females and C. sexes of L. sceleratus using Total and gutted weight.

\begin{tabular}{lll}
\hline $\mathrm{W}=0.012 \mathrm{~L}^{2.957}$ & $\mathrm{r}=0.984$ & Males \\
$\mathrm{W}=0.013 \mathrm{~L}^{2.933}$ & $\mathrm{r}=0.997$ & $\begin{array}{l}\text { Females } \\
\text { All specimens } \\
\text { (Combined sexes) }\end{array}$ \\
$\mathrm{W}=0.013 \mathrm{~L}^{2.938}$ & $\mathrm{r}=0.996$ & Males \\
$\mathrm{Wgut}=0.013 \mathrm{~L}^{2.908}$ & $\mathrm{r}=0.994$ & Females \\
Wgut $=0.014 \mathrm{~L}^{2.896}$ & $\mathrm{r}=0.997$ & $\begin{array}{l}\text { All specimens } \\
\text { (Combined sexes) }\end{array}$ \\
Wgut $=0.014 \mathrm{~L}^{2.901}$ & $\mathrm{r}=0.997$ & \\
\hline
\end{tabular}

Applying t-test on the data of mean weight-at-length for males and females showed insignificant difference $(\mathrm{P}>0.05)$, therefore the relations was applied for combined sexes as shown in figs. $(2,3)$.

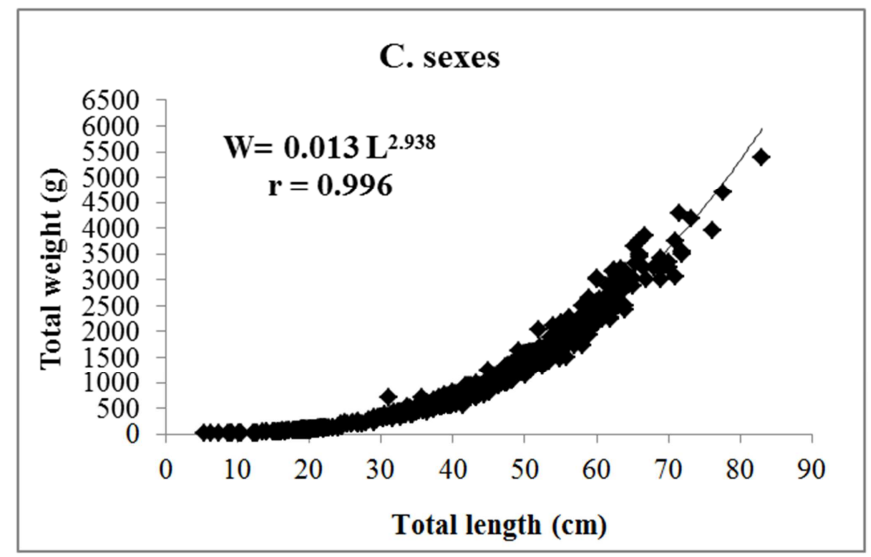

Figure 2. Length-weight relationship in C. sexes of L. sceleratus using total weight.

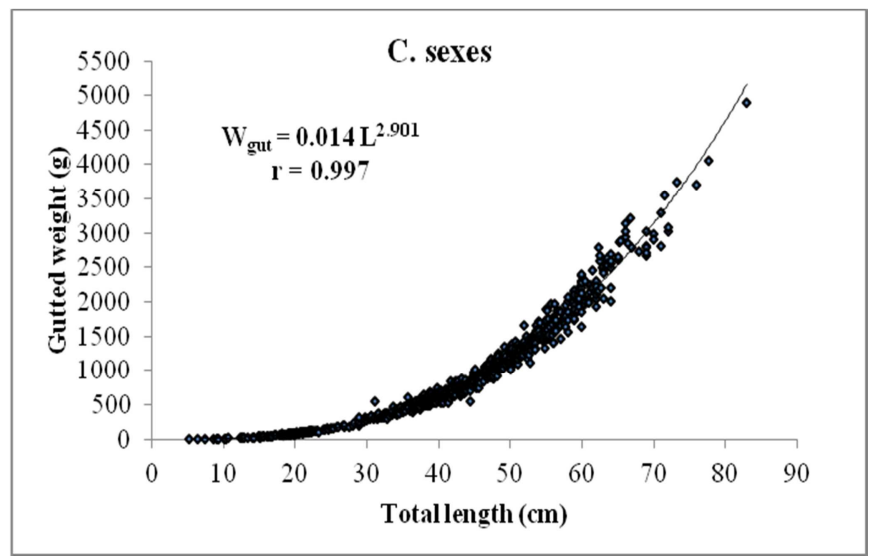

Figure 3. Length-weight relationship in C. sexes of L. sceleratus using gutted weight.

The annual average of condition factor $(\mathrm{K})$ was $0.97 \pm 0.089$ for combined sexes where males and females were almost 
similar and constant all over the year except in July it was little higher. The immature individuals showed slightly higher condition factor than mature individuals with fluctuations along years with slightly increase during June (fig. 4). According to length group, the condition factor exhibited decline trend as the length increase. The highest value was observed for smaller length groups of males, while, the lowest values for largest length group of females (fig. 5).

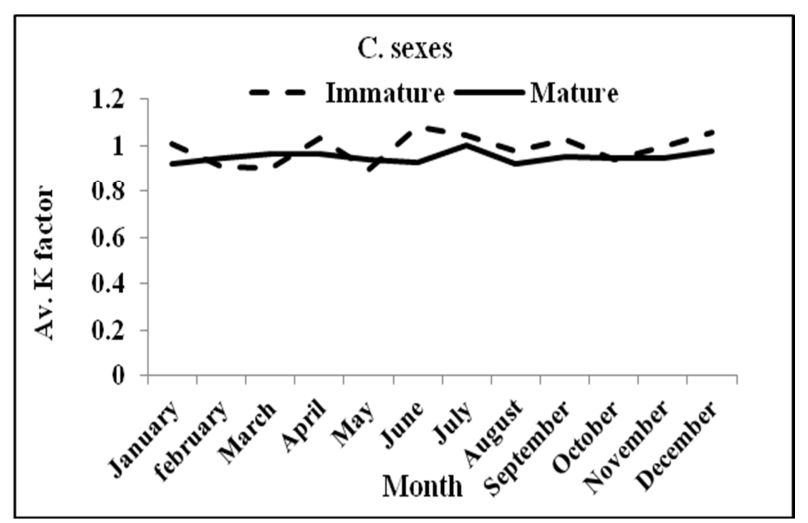

Figure 4. Monthly changes of condition factor $(K)$ according to maturation for C. sexes.

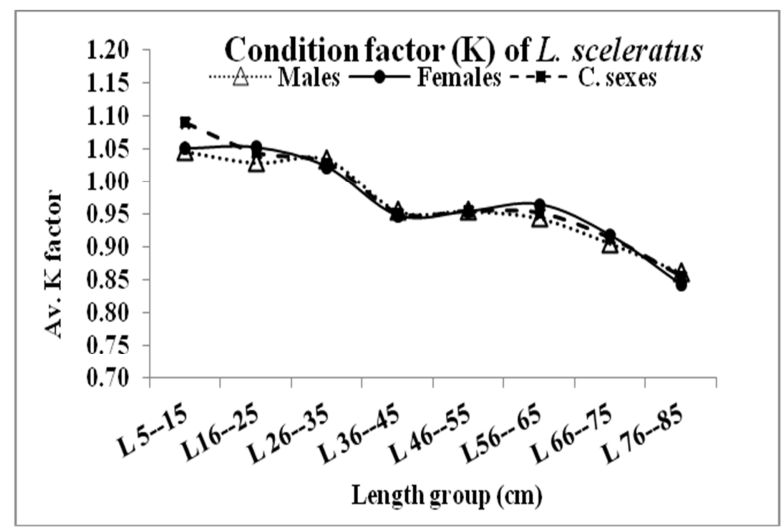

Figure 5. Trend of condition factor (K) according to length groups for males, females and C. sexes.

Age was determined using 1736 specimens of L. sceleratus sorted into different length groups with length interval of $3 \mathrm{~cm}$ for length frequency analysis, in addition to reading of 190 vertebrae for validation of the age, (Figs. $6 \& 7$ ) both methods showed seven years old. The mean lengths at each year of life for both methods are shown in Table (2). For length frequency analysis, the mean Length at the end of each year of life for all samples were 18.03, 32.70,42. 54, 52.23, 60.5, 68.5 and 76.5 $\mathrm{cm}$ for $1^{\text {st }}, 2^{\text {nd }}, 3^{\text {rd }}, 4^{\text {th }}, 5^{\text {th }}, 6^{\text {th }}$ and $7^{\text {th }}$ years of life respectively. Age composition for unsexed specimens revealed that age group III was most abundance (40.53\%) followed by age group IV (26.52\%); while age group VII was few $(0.20 \%)$ as shown in Fig. (8).

The specimens were sorted in to males, females for reading of vertebrae. The results showed seven years old for both sexes. The statistical test (t-test) showed no significant difference at $\mathrm{P}>0.05$ between the length at age of both males and females. Therefore, the mean lengths at the end of each year of life for combined sexes were estimated as 18.01, 34.03, $43.73,52.76,61.23,68.92$ and $74.95 \mathrm{~cm}$ for the sequences years respectively.

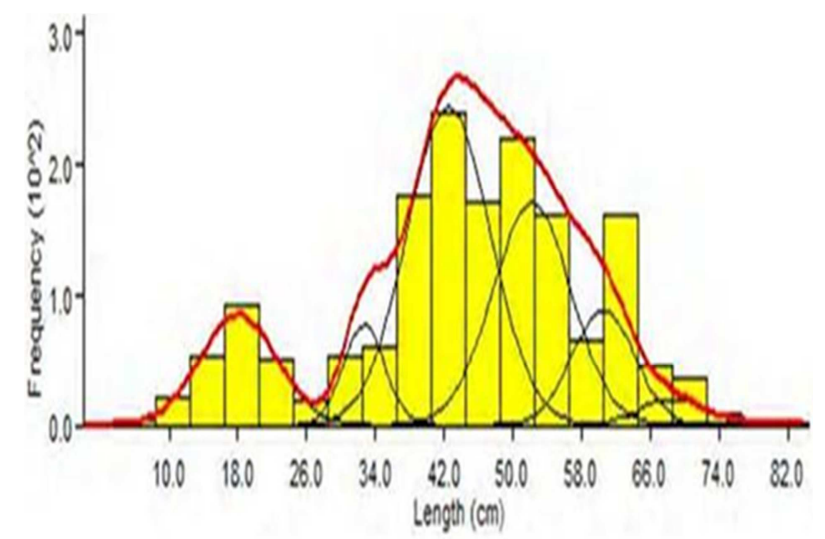

Figure 6. Length frequency distribution for C. sexes of L. sceleratus using Bhattacharya method.

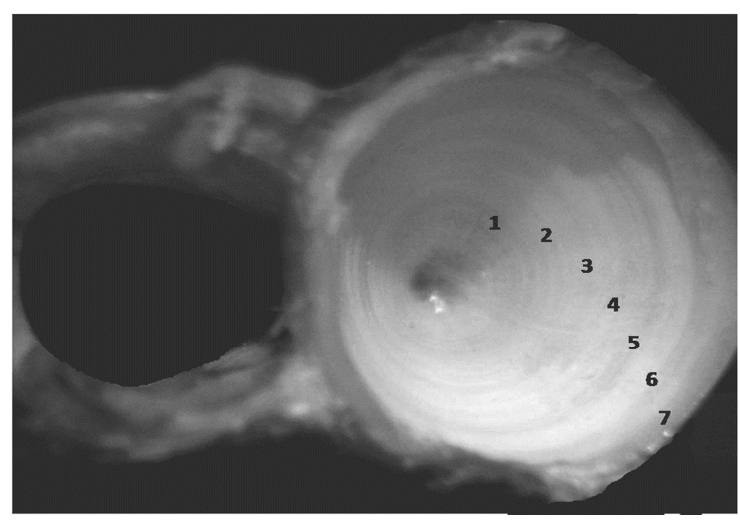

Figure 7. Whole Vertebrae of L. sceleratus (Female, VII age groups, $76 \mathrm{~cm}$ $T L)$.

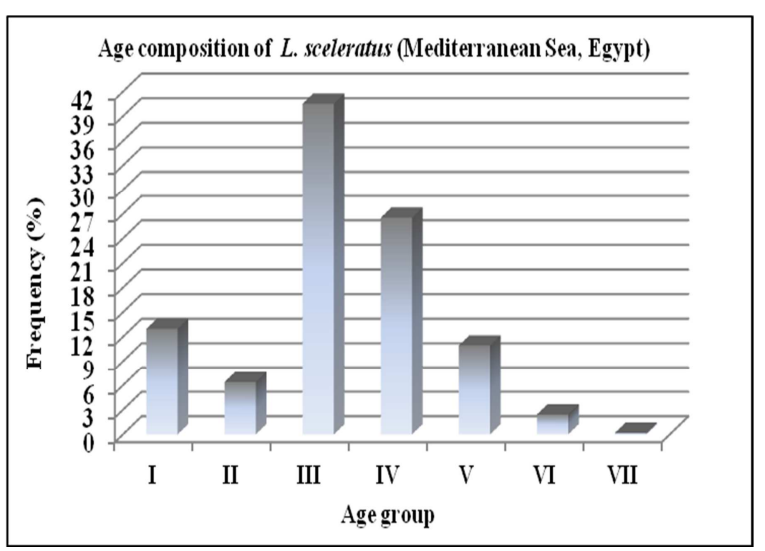

Figure 8. Age composition of L. sceleratus using Bhattacharya method. 


\section{American Journal of Life Sciences}

2015; 3(6-1): 83-93

Published online November 28, 2015 (http://www.sciencepublishinggroup.com/j/ajls) doi: $10.11648 /$ j.ajls.s.2015030601.22

ISSN: 2328-5702 (Print); ISSN: 2328-5737 (Online)

Table 2. Mean lengths at each year of life for L. sceleratus by both methods.

\begin{tabular}{|c|c|c|c|c|c|c|c|}
\hline \multirow{3}{*}{$\begin{array}{l}\text { Age } \\
\text { group }\end{array}$} & \multirow{3}{*}{$\begin{array}{l}\text { Bhattacharya } \\
\text { Mean Length } \\
\text { (cm) }\end{array}$} & \multicolumn{6}{|l|}{ Vertebrae } \\
\hline & & \multicolumn{2}{|l|}{ Males } & \multicolumn{2}{|l|}{ Females } & \multicolumn{2}{|l|}{ C. sexes } \\
\hline & & Mean length (cm) & $\begin{array}{l}\text { Length range } \\
(\mathrm{cm})\end{array}$ & Mean length (cm) & $\begin{array}{l}\text { Length range } \\
(\mathrm{cm})\end{array}$ & $\begin{array}{l}\text { Mean length } \\
(\mathrm{cm})\end{array}$ & $\begin{array}{l}\text { Length range } \\
(\mathrm{cm})\end{array}$ \\
\hline 0 & & 0 & 0 & 0 & 0 & 0 & $9-14$ \\
\hline I & 18.03 & 18. 56 & $16-25$ & 17.47 & $14-24$ & 18.01 & $14-25$ \\
\hline II & 32.7 & 34.98 & $24-38$ & 33.08 & $23-40$ & 34.03 & $23-40$ \\
\hline III & 42.54 & 44.83 & $38-52$ & 42.78 & $38-51$ & 43.76 & $38-52$ \\
\hline V & 60.5 & 62.51 & $50.9-69$ & 59.94 & $50-69$ & 61.23 & $50-69$ \\
\hline VI & 68.5 & 69.98 & $65.5-72$ & 67.86 & $66-71$ & 68.92 & $65.5-72$ \\
\hline VII & 76.5 & 75.94 & $70-78$ & 73.96 & $66.5-76$ & 74.95 & $66.5-78$ \\
\hline
\end{tabular}

Von Bertalanffy growth model was fitted using age-length data for combined sexes of both ageing methods. For length frequency analysis, the growth parameters were estimated as $\mathrm{L}_{\infty}=106.34 \mathrm{~cm}, \mathrm{~K}=0.17$ year $^{-1}$ and $\mathrm{t}_{\mathrm{o}}=0.0228$ year $^{-1}$, while for vertebrae data as $\mathrm{L}_{\infty}=101.63 \mathrm{~cm}$ and $\mathrm{K}=0.189$ year $^{-1}$ and $\mathrm{t}_{\mathrm{o}}=$ 0.1186 . Growth performance index (Ø) was found to be 3.28 and 3.289 for all samples derived from Bhattacharya and Vertebrae methods respectively.

Population parameters were calculated as shown in Table
(3): total mortality ( $Z$ ) by length converted catch curve method is shown in Fig. (9) was estimated as 1.01 year $^{-1}$, natural mortality $(\mathrm{M})=0.347$ year $^{-1}$, fishing mortality $(\mathrm{F})=$ 0.663 year $^{-1}$, survival rate $(\mathrm{S})=0.364$ year $^{-1}$ and exploitation ratio $(E)=0.657$. The length and age at first capture $\left(\mathrm{L}_{\mathrm{c}} \& \mathrm{~T}_{\mathrm{c}}\right)$ were estimated as $32.34 \mathrm{~cm}$ and 2.156 year for respectively. While the length and age at recruitment $\left(\mathrm{L}_{\mathrm{r}} \& \mathrm{~T}_{\mathrm{r}}\right)$ were estimated as $25.95 \mathrm{~cm}$ and 1.67 year respectively.

Table 3. Population parameters of L. sceleratus from the Egyptian Mediterranean water.

\begin{tabular}{|c|c|c|c|c|c|c|c|c|c|c|}
\hline Sex & Lagocephal & sceleratus (M & terranean c & Egypt) & & & & & & \\
\hline \multirow{2}{*}{ C. sexes } & $\mathrm{Z}$ (year -1) & M (year -1) & F (year -1) & S & $\mathbf{E}$ & Lc (cm) & Tc (year) & Lr (cm) & $\operatorname{Tr}$ (year) & $\mathbf{W} \infty$ \\
\hline & 1.01 & 0.3468 & 0.663 & 0.364 & 0.657 & $32.34 \mathrm{~cm}$ & 2.156 ear & 25.95 & 1.67 & $10606.57 \mathrm{~g}$ \\
\hline
\end{tabular}

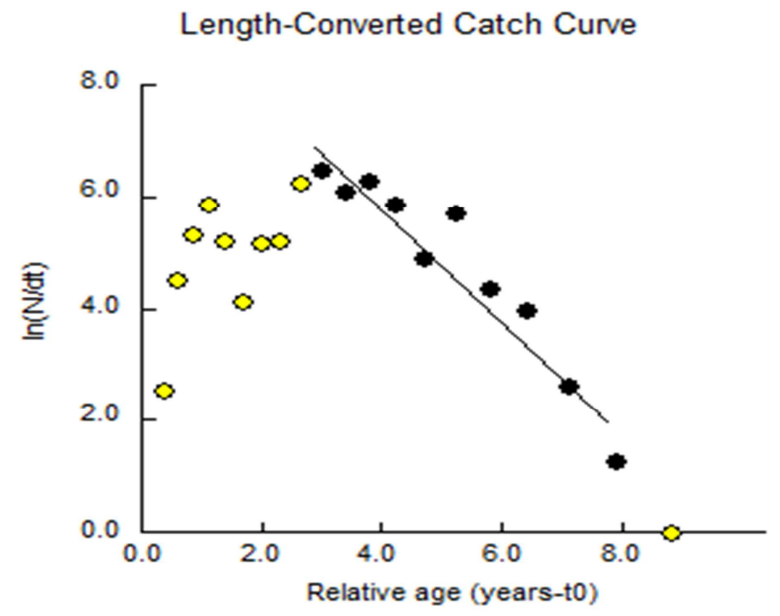

Figure 9. Length converted catch curve of total mortality of L. sceleratus.

Using $\mathrm{W}_{\infty}=10606.572 \mathrm{~g}$, yield and biomass per recruit $(\mathrm{Y} / \mathrm{R}$ and $\mathrm{B} / \mathrm{R})$ were estimated as 447.26 \& $674.61 \mathrm{~g}$ respectively at current $(\mathrm{F})=0.663$ year $^{-1}$ and $\mathrm{Tc}=2.156$ year. The maximum sustainable yield per recruit (MSY) was $467.42 \mathrm{~g}$; it is estimated at fishing mortality $\left(\mathrm{F}_{\mathrm{MSY}}\right) 0.403$ year ${ }^{-1}$ Which is lower than current fishing mortality.

By changing the values of age at first capture with fishing mortalities levels, the yield per recruit showed an increase as the increase of age at first capture $(\mathrm{Tc}=3.156)$ reaching 715 .
$32 \mathrm{~g}$ and the biomass per recruit 1078. $91 \mathrm{~g}$ at the same current fishing mortality $\left((\mathrm{F})=0.663\right.$ year $\left.^{-1}\right)$ Figs. $(10 \mathrm{a}, \mathrm{b})$.

Moreover, the yield per recruit has increased to reach the maximum sustainable yield (MSY) with increase of age at first capture (Tc) and fishing mortality giving value of 715 . $359 \mathrm{~g}$ at fishing mortality $\left(\mathrm{F}_{\mathrm{MSY}}\right) 0.703$ year $^{-1}$ and higher $\mathrm{Tc}=$ 3.156. Generally, the yield per recruit at current parameters $(F$, Tc and E) was lower than that obtained at the optimum exploitation $(E=0.50)$ and those of maximum sustainable yield per recruit at $\left(\mathrm{F}=0.403\right.$ year $\left.^{-1}\right)$ and $(\mathrm{E}=0.537)$, although the current fishing mortality was higher than those at optimum exploitation and maximum sustainable yield per recruit showing high level exploitation.

The yield per recruit at the biological reference points $\left(\mathrm{F}_{0.1}\right.$ $\& F_{\max }$ ) were $423.72 \mathrm{~g}$ and $467.42 \mathrm{~g}$ respectively (Fig. 11). The fishing mortalities at these points were 0.203 year $^{-1}$ and 0.403 year ${ }^{-1}$ for $F_{0.1}$ and $F_{\max }$ respectively giving lower values than current fishing mortality 0.663 year $^{-1}$ that gave yield per recruit (447.26 g). The yield per recruit $\left(467.42 \mathrm{~g}\right.$ ) at $\mathrm{F}_{\max }$ was higher than that obtained at present fishing mortality $\mathrm{F}_{\text {pre }}$. and at $\mathrm{F}_{0.1}$. The biomass per recruit at different biological references showed higher percentage $(41.23 \%)$ of the target reference point $\left(\mathrm{F}_{0.1}\right)$ than those of $\mathrm{F}_{\max }(22.91 \%) \& \mathrm{~F}_{\text {present or }}$ current $(13.33 \%)$. The obtained results showed that present fish population is overexploited; the fishing mortality should be reduced to the certain levels at which the values of $Y / R$ at $F_{0.1}$ 
can get.
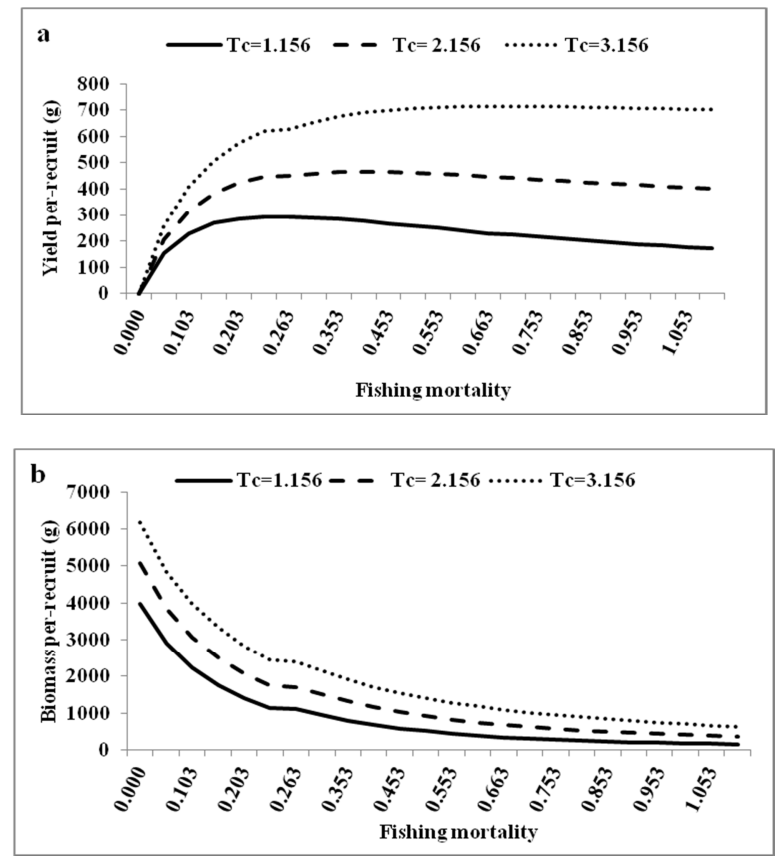

Figure 10. $a$; Yield per recruit $(Y / R)$ and $b$; biomass per recruit $(B / R)$ in gram of $L$. sceleratus at different values of fishing mortality $(F)$ and age at first capture $\left(T_{c}\right)$.

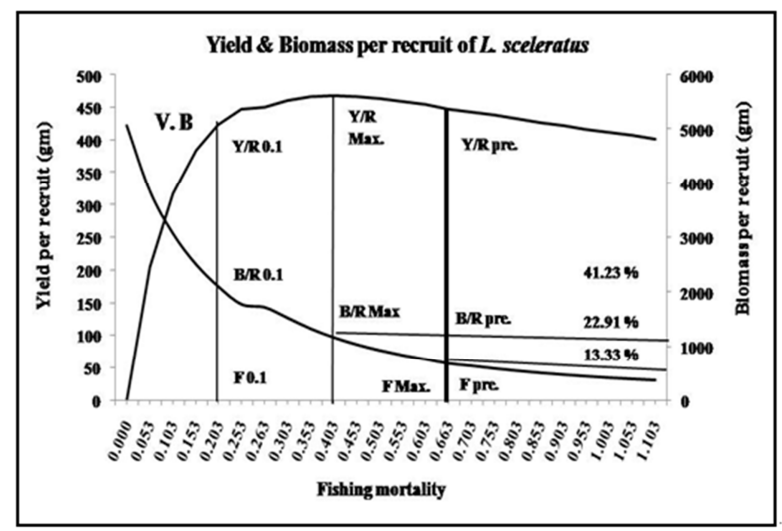

\section{Discussion}

The effective management of a fish stock is of important for the sustainable of that stock $[42,50]$. The present observed total length of $L$. sceleratus from the Egyptian Mediterranean waters ranged from 5 to $83 \mathrm{~cm}$ regardless sex. This range is wider than that reported by [30] from Suez Gulf, Red Sea, Egypt (18. 5-78. $5 \mathrm{~cm}$ ); by [51] from Antalya Bay, Turkey's Mediterranean Sea $(12.5-65 \mathrm{~cm})$; from Israeli coast (5-56.5 $\mathrm{cm})$ by [52] and from Lebanon coast $(20.5-73.5 \mathrm{~cm})$ by [53] The variations in length range may due to variations in the period of samples collection and fishing gear selectivity, however the presence of present length range as larger one may indicates the suitability of new habitats and its establishing well. Simon and Mazlan [5] stated that length range of L. sceleratus from estuarine water, Peninsular Malaysia was $11.2-18.3 \mathrm{~cm}$ very smaller than that of the present and other studies. This may due to that usually the estuarine areas characterized by shallow water, the smaller size of samples from Malaysia supported by that the small size puffer fish prefer the shallower coastal area cited in [54]. For applied ichthyological studies, 'b' of length-weight relationship seems to be important as a key parameter in estimating population growth [55, 5]. From table (4) the present values of exponent " $b$ " were 2.938 and 2.901 for total weight and gutted weight respectively, both of them were less than " 3 " for all samples reflecting negative allometric growth. This mode of growth was nearly the same as those recorded by $[56,30,5,51,52,57,53]$. While, the present results differed from that of [58] who reported that "b" value3.018 was slightly higher than " 3 " (Positive allometric growth).This difference may due to variations in habitats, biological, environmental conditions, or even the used of narrow length range where the later author used length range $(11.2-18.3 \mathrm{~cm})$.

Figure 11. Yield per recruit and biomass per recruit curves of L. sceleratus showing biological reference points.

Table 4. Length weight relationship parameters, absolute $(K)$ conditions of L. sceleratus from different locations.

\begin{tabular}{|c|c|c|c|c|c|c|c|c|c|c|}
\hline Author & Location & $\begin{array}{l}\text { No. } \\
\text { samples }\end{array}$ & $\begin{array}{l}\text { L. range } \\
(\mathrm{cm})\end{array}$ & W. range (g) & Sex & $\mathbf{a}$ & b & $\mathbf{r}$ & $\begin{array}{l}\text { Collection } \\
\text { period }\end{array}$ & $\mathbf{K}$ \\
\hline $\begin{array}{l}\text { Kulbicki et al. } \\
(2005)\end{array}$ & ----- & ----- & ------ & ----- & C. sexes & -------- & 2.920 & --------- & ------- & -------- \\
\hline $\begin{array}{l}\text { Sabrah et al. } \\
(2006)\end{array}$ & Suez Gulf & ------ & $18.5-78.5 \mathrm{~cm}$ & 82. $9-5100 \mathrm{~g}$ & $\begin{array}{l}\text { Males } \\
\text { Females } \\
\text { C. sexes }\end{array}$ & $\begin{array}{l}0.016099 \\
0.020902 \\
0.018712\end{array}$ & $\begin{array}{l}2.9044 \\
2.8418 \\
2.8676\end{array}$ & $\begin{array}{l}0.99 \\
0.991 \\
0.994\end{array}$ & $\begin{array}{l}\text { October } 2002 \text { to } \\
\text { June } 2003\end{array}$ & - \\
\hline $\begin{array}{l}\text { Simon \& } \\
\text { Mazlan (2008) }\end{array}$ & $\begin{array}{l}\text { Estuaries of south } \\
\text { Johore, Peninsular } \\
\text { Malaysia }\end{array}$ & 148 & $11.2-18.3 \mathrm{~cm}$ & $\begin{array}{l}13.41-275 . \\
31 \mathrm{~g}\end{array}$ & C. sexes & 0.0133 & 2. 99 & 88.0 & $2006 \& 2007$ & 13. $057 \pm 0$. \\
\hline $\begin{array}{l}\text { Michailidis } \\
(2010)\end{array}$ & Cyprus & & 6. $0-77.0 \mathrm{~cm}$ & 3. $0-5600 \mathrm{~g}$ & C. sexes & --------- & 3. 018 & --------- & --------- & --------- \\
\hline Aydın (2011) & $\begin{array}{l}\text { Antalya Bay, } \\
\text { Turkey's } \\
\text { Mediterranean Sea }\end{array}$ & 656 & 12. $5-65 \mathrm{~cm}$ & $\begin{array}{l}22.8-3463 \mathrm{~g} \\
29-3465 \mathrm{~g}\end{array}$ & $\begin{array}{l}\text { Males } \\
\text { Females } \\
\text { C. sexes }\end{array}$ & $\begin{array}{l}0.012 \\
0.011 \\
0.012\end{array}$ & $\begin{array}{l}2.974 \\
2.984 \\
2.979\end{array}$ & $\begin{array}{l}0.997 \\
0.997 \\
0.998\end{array}$ & $\begin{array}{l}\text { Dec. } 2008 \\
\text { to Janu. } 2010\end{array}$ & $\begin{array}{l}\text { 1. } 14 \pm 0.10 \\
\text { 1. } 13 \pm 0.10 \\
\text { 1. } 14 \pm 0.10\end{array}$ \\
\hline Edelist ( 2012) & Israeli coast & ---- & $5-56.5 \mathrm{~cm}$ & & C. sexes & 0.0225 & 2. 820 & 0.991 & 2008 & ------- \\
\hline Başusta et al. & Iskenderun Bay, & ----- & $8.9-78.4 \mathrm{~cm}$ & 7. $59-4750 \mathrm{~g}$ & Males & 0.0381 & 2. 6446 & 0.969 & Sept. 2011 to & ------- \\
\hline
\end{tabular}




\begin{tabular}{|c|c|c|c|c|c|c|c|c|c|c|}
\hline Author & Location & $\begin{array}{l}\text { No. } \\
\text { samples }\end{array}$ & $\begin{array}{l}\text { L. range } \\
(\mathrm{cm})\end{array}$ & W. range (g) & Sex & $\mathbf{a}$ & b & $\mathbf{r}$ & $\begin{array}{l}\text { Collection } \\
\text { period }\end{array}$ & $\mathbf{K}$ \\
\hline (2013) & $\begin{array}{l}\text { Mediterranean, } \\
\text { Turkey }\end{array}$ & & $15.4-52.3 \mathrm{~cm}$ & 37. $04-1324 \mathrm{~g}$ & Females & 0.0138 & 2. 915 & 0.986 & march 2012 & \\
\hline $\begin{array}{l}\text { Kalogirou } \\
(2013)\end{array}$ & $\begin{array}{l}\text { Rhodes, Eastern } \\
\text { Mediterranean Sea }\end{array}$ & ----- & To $64 \mathrm{~cm}$ & ----- & ------ & 0.0164 & 2. 8932 & 0.999 & 2008-2009 & -------- \\
\hline $\begin{array}{l}\text { Boustany et al. } \\
\text { (2015) }\end{array}$ & $\begin{array}{l}\text { Lebanon coast, } \\
\text { Mediterranean sea }\end{array}$ & 132 & $20.5-73.5$ & 82. $79-5170 \mathrm{~g}$ & C. sexes & 0.143 & 2.99 & 0.975 & $\begin{array}{l}\text { Jan2011-Jul. } \\
2012\end{array}$ & \\
\hline $\begin{array}{l}\text { Present work } \\
\text { (using total } \\
\text { weight) }\end{array}$ & $\begin{array}{l}\text { Mediterranean } \\
\text { coast, Egypt }\end{array}$ & 795 & $5-83 \mathrm{~cm}$ & 2. $1-5400 \mathrm{~g}$ & $\begin{array}{l}\text { Males } \\
\text { Females } \\
\text { C. sexes }\end{array}$ & $\begin{array}{l}0.012 \\
0.013 \\
0.013\end{array}$ & $\begin{array}{l}2.957 \\
2.933 \\
2.938\end{array}$ & $\begin{array}{l}0.984 \\
0.997 \\
0.996\end{array}$ & 2012 & $\begin{array}{l}--- \\
---- \\
-----\end{array}$ \\
\hline
\end{tabular}

Condition factor ( $\mathrm{k}$ ) is used as indicator of the well being and relative robustness of the fish population; it can be varied with length, weight, season and habitat for the same species [59]. In the present work, the variation of condition factor of $L$. sceleratus during the whole year showed the slightly fluctuations showing no obvious trend to sharp increase or decrease, except the highest value (1.03) which recorded in July and this may correlates to spawning activity. The present annual average values of conditions which were slightly near "1" for males, females and C. sexes indicating suitable conditions for growth of such species in Egyptian Mediterranean waters with no obvious difference in condition between males and females. Regardless the values of conditions, this trend was in agreement with that of [51] from Antalya Bay, Turkey's where its males, females and combines sexes had nearly the same values of conditions, while the similarity with those of [14] from Rhodes, Eastern Mediterranean Sea that situated in the same trend of fluctuation along the year with the increase in summer confirming good condition in Mediterranean Sea..

From another point of view, the present results disagreed with that of [5], of L. sceleratus from estuaries of south Johore, Peninsular Malaysia, who stated high value of the mean of condition factor $(\mathrm{K})$ that was 13. $057 \pm 0$. 2008. This difference may due to using another index $\left(\mathrm{K}=1000 \mathrm{~W} / \mathrm{L}^{3}\right)$ to estimate the well being of this species instead of the present index $\left(\mathrm{K}=100 \mathrm{~W} / \mathrm{L}^{3}\right)$, even during the use of same index, its value is still higher than present value, and this may attribute to variations in it habitats, length range used which confirmed by the present study where the smaller length group had higher condition factor. The present condition also does not seem to be affected much or obviously by reproductive activity, this may lie in the major importance of the liver as an organ for storage as supported by [60].

Regarding maturation, the mature individuals who showed slightly increase during July referring the constant well being for this species along different months and the increase during July may relate to spawning activity. According to length, the condition factor decreased as the fish increase in length reflecting the accordance with growth pattern which was high during small length groups then decreased along larger length group, this pattern may due to the requirements of maturation for these large length groups. Le- Cren [31], stated that the condition values equal to/or greater than one reflect good condition of growth, in the present work the values of mean the conditions were slightly equal to " 1 " for male, female and C. sexes, and also through classification into immature and mature individuals, the average values were nearly equal " 1 " which indicates that this species showed good growth mode \& condition in new habitats.

Puffer fishes and other non-indigenous species (NIS), have been established their selves in the ecosystem of the Eastern Mediterranean suggesting that the conditions are becoming more and more suitable for the growth, reproduction and survival of tropical species offering the aliens various advantages when competing with native species [61, 29, 62, 63]. Age and growth are the most important characteristic features and specific for each fish species. They have an adaptive property, ensured by the unity of the species and its environment [64]. The maximum age of L. sceleratus estimated by both methods (length frequency and vertebrae) was seven years old. This result agreed with the result of [51] on the same species from Turkey's Mediterranean Sea. While it disagreed with the results of [30] from the Gulf of Suez; Red Sea, Egypt, they reported that the maximum age of $L$. sceleratus was ten years (Table 5). This difference may be due to different habitats, number of specimens; however this confirms the suitability and favorable conditions for this immigrant fish to Mediterranean Sea as new ground to reach seven years old within larger length range than red sea. Regarding age composition, it is evident that age group III was dominated the catch and more abundance $(40.53 \%)$ followed by age group IV (26. $52 \%$ ); indicating the effect of fishing gear selectivity particularly long line which consider the main fishing methods used to catch pufferfish targeting larger and older fishes as cited in [54].

Table 5. Calculated lengths at age groups of L. scelertus from different localities.

\begin{tabular}{|c|c|c|c|c|c|c|c|c|c|c|c|c|c|c|}
\hline \multirow{2}{*}{ Author } & \multirow{2}{*}{ Location } & \multirow{2}{*}{ L. range $(\mathrm{cm})$} & \multirow{2}{*}{ Method } & \multicolumn{11}{|c|}{ Age groups (Calculated length cm) } \\
\hline & & & & $\mathbf{0}$ & I & II & III & IV & $\mathbf{V}$ & VI & VII & VIII & IX & $\mathbf{X}$ \\
\hline $\begin{array}{l}\text { Sabrah et } \\
\text { al. (2006) }\end{array}$ & $\begin{array}{l}\text { Suez Gulf, Red Sea, } \\
\text { Egypt }\end{array}$ & $18.5-78.5 \mathrm{~cm}$ & L. F & 18.5 & 24. 27 & 34.2 & 44. 2 & 50.98 & 56.15 & 61.11 & 65.43 & 69.94 & 74. 4 & 78.8 \\
\hline
\end{tabular}




\begin{tabular}{|c|c|c|c|c|c|c|c|c|c|c|c|c|c|c|}
\hline \multirow{2}{*}{ Author } & \multirow{2}{*}{ Location } & \multirow{2}{*}{ L. range (cm) } & \multirow{2}{*}{ Method } & \multicolumn{11}{|c|}{ Age groups (Calculated length cm) } \\
\hline & & & & $\mathbf{0}$ & $\mathbf{I}$ & II & III & IV & $\mathbf{V}$ & VI & VII & VIII & IX & $\mathbf{X}$ \\
\hline $\begin{array}{l}\text { Aydın } \\
(2011)\end{array}$ & $\begin{array}{l}\text { Antalya Bay, Turkey's } \\
\text { Mediterranean Sea }\end{array}$ & 12. $5-65 \mathrm{~cm}$ & L. F & ---- & 17. 08 & 27.03 & 37.42 & 44.5 & 53.53 & 59.97 & -- & --- & --- & ----- \\
\hline \multirow{2}{*}{$\begin{array}{l}\text { Present } \\
\text { work }\end{array}$} & \multirow{2}{*}{$\begin{array}{l}\text { Mediterranean coast, } \\
\text { Egypt }\end{array}$} & \multirow{2}{*}{$5-83 \mathrm{~cm}$} & L. F & ----- & 18. 03 & 32.7 & 42.54 & 52.23 & 60.5 & 68.5 & 76.5 & --- & ---- & ----- \\
\hline & & & Vertebrae & ----- & 18. 01 & 34.03 & 43.76 & 52.76 & 61.23 & 68.92 & 74. 95 & ---- & ---- & ---- \\
\hline
\end{tabular}

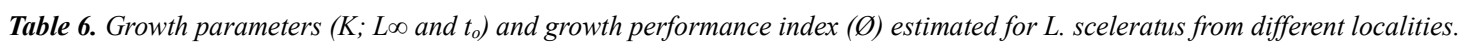

\begin{tabular}{|c|c|c|c|c|c|c|}
\hline Author & Location & Method & $\mathbf{L} \infty(\mathrm{cm})$ & K (year-1) & to (year) & $\varnothing$ \\
\hline Chan and Liew (1986) & Malaysia & ------- & 18 & 1.5 & ----- & 2.69 \\
\hline \multirow{2}{*}{ Sabrah, et al. (2006) } & \multirow{2}{*}{ Gulf of Suez, Red Sea, Egypt. } & L. frequency & 3.82 & 191.0 & ------ & 3.11 \\
\hline & & L. frequency & 81.1 & 0.26 & ----- & 3.23 \\
\hline Aydın (2011) & Antalya Bay Turkey's Mediterranean Sea & & 126.11 & 0.099 & -0.43 & 3. 20 \\
\hline \multirow{2}{*}{ Present work, 2011, 2012} & \multirow{2}{*}{ Mediterranean coast, Egypt } & L. frequency & 106.34 & 0.17 & 0.0228 & 3.28 \\
\hline & & Vertebrae & 108.78 & 0.17 & 0.1186 & 3. 289 \\
\hline
\end{tabular}

The highest growth in length $18.03 \& 18$. at the first age group for length frequency and vertebrae respectively, disagreed with those of [30] in Suez Gulf, Red Sea, Egypt and that from Antalya Bay, Turkey's Mediterranean Sea by [51] who reported that the highest growth in length was observed at the second and third age group. This difference may due to the difference in number of age group for the different studies. While, the poor growth pattern after the first year of life may be associated with the onset of maturity, which often causes a discontinuity in the growth curve [42].

Growth parameters $\left(\mathrm{L}_{\infty}, \mathrm{K}\right.$ and $\left.\mathrm{t}_{\mathrm{o}}\right)$ and growth performance $(\varnothing)$ are the basic input data into various models used for managing and assessing the status of the exploited fish stocks, these parameters facilitate the comparison between growth of fishes belonging to different species or to the same species at different times and different localities. From table (6), the present estimates $\left(\mathrm{L} \infty, \mathrm{K}\right.$ and $\left.\mathrm{t}_{\mathrm{o}}\right)$ are disagreed with those of $[65,30,51]$. Such difference may be attributed to difference in length range, the method used to evaluate asympotitic length or due to the environmental conditions under which a fish lives as mentioned by [66]. Moreover, the difference may be related to the number of specimens and growth in length in relation to specifity to age groups of each population which play important role in investigation of growth parameters.

Growth performance index is used to compare the growth rate of fish species with other species [38]. The present indices of $(\varnothing)$ were 3. 28 and 3. 289 for both methods of length frequency and vertebrae respectively, they were larger than those obtained by [65] from Malaysia; and [30] from Gulf of Suez, Red Sea, Egypt and from Antalya Bay Turkey's Mediterranean Sea by [51] indicating better growth performance of the Mediterranean population.

Due to the insignificant difference between the both methods of aging (length frequency and vertebrae) and the high number of specimens that used in length frequency. The data of length frequency for all samples regardless sex were used to be basic input data for population dynamics and stock assessment of $L$. sceleraus from the Egyptian Mediterranean waters. Any population of species is maintained by the equilibrium between its birth and death rates [67]. The instantaneous total mortality coefficient $(Z)$ in the present study was estimated as 1.01 year $^{-1}$, with fishing mortality $(\mathrm{F})$ equals $0.663(65.64 \%)$ reflecting an over-fishing condition on the stock of puffer fish in the Egyptian Mediterranean waters. The present survival rate (S) was found to be 0.364 . The lower value of survival rate confirmed the critical situation of the present investigated stock. The optimum exploitation rate was suggested as 0.50 where the optimum fishing mortality equal the natural mortality $(\mathrm{F}=\mathrm{M})$, if this value was highly more than the optimum value (0.5) this revealed that this fish is over exploited fish as suggested by [45].The present exploitation rate was 0.657 revealing the overexploitation status of L. sceleratus in the Egyptian Mediterranean waters regardless the Ministry decree of prohibiting fishing of Puffer fish.

The length at first capture $\left(\mathrm{L}_{\mathrm{c}}\right)$ and $\left(\mathrm{L}_{\mathrm{r}}\right)$ and that of first sexual maturity $\left(\mathrm{L}_{\mathrm{m}}\right)$ as well as their corresponding ages consider as indicators for stock status. The present values of $\mathrm{L}_{\mathrm{c}}$ and $\mathrm{L}_{\mathrm{r}}$ were estimated as $32.34 \mathrm{~cm}$ and $25.95 \mathrm{~cm}$ respectively, they were lower than the mean length of the catch of the present population $(\mathrm{L}-=43.003 \mathrm{~cm})$ explaining the higher fishing mortality. The length at first sexual maturity $\left(\mathrm{L}_{\mathrm{m}}=\right.$ $38.5 \mathrm{~cm}$ ) that calculated by [66] for the same population was higher than the value of length at first capture $\left(\mathrm{L}_{\mathrm{c}}=32.34 \mathrm{~cm}\right)$ indicating difficulties of puffer fish to spawning at least once before being fished.

The yield per recruit model predicts the ratio of the mass of fish caught during the life span to the initial abundance when it enters the fishing grounds [42], it is one of the basic assessments of fish stocks [68]. The yield per recruit is affected by many factors as the age at first capture as cited in [69]. So, the present yield per recruit (Y/R) at sequence of fishing mortalities with various values of age at first capture decreased with the increase of fishing mortality. While $\mathrm{Y} / \mathrm{R}$ increase with the increase of $T_{c}$ till it reaches its maximum then it decreases.

The maximum sustainable yield per recruit at current age at first capture was observed at $\mathrm{E}=0.537$, or less than the current exploitation rate $(\mathrm{E}=0.656)$ reflecting the high pressure on stock suggesting reduce the exploitation rate to be 
less than optimum $\mathrm{E}$ value (i. e. 0.5 ) or $\mathrm{E}=0.466$ and fishing mortality $\mathrm{F}=0.303$ (decrease to $29.07 \%$ of the current value of exploitation rate) to produce $\mathrm{Y} / \mathrm{R}=459.89 \mathrm{~g}$ (increase with 2. $75 \%$ of the current value of yield per recruit) and $B / R$ to 1517. 0 suggesting increase the current $t_{c}$ from 2.16 year to 3.16 year to reach $\mathrm{E}=0.466$ and $\mathrm{F}=0.303$ (decrease $29.07 \%$ of the original value) to produce $\mathrm{Y} / \mathrm{R}=653.725 \mathrm{~g}$ (increase to $29.65 \%$ of the value at current $t_{c}$ at this rate of exploitation) and $\mathrm{B} / \mathrm{R}=2157.507 \mathrm{~g}$. This rate of exploitation $(\mathrm{E}=0.466)$ insure the increase of yield per recruit at current and higher length at first capture with further increase in fishing effort.

Biological reference points could use as indicators for the state of a fishery at which management plans should be set or for optimizing the limit of fishing mortality. The present values of $F_{\max } \& F_{0.1}$ were found to be less than the current fishing mortality (0.663) which gave 447. 26g (Y/R). The present value of $\mathrm{F}_{\max }$ was 0.403 year $^{-1}$ gave $467.42 \mathrm{gY} / \mathrm{R}$, while the value of $F_{0.1}$ was 0.203 year $^{-1}$ gave $423.72 \mathrm{gY} / \mathrm{R}$. Inspite of the fishing mortality at maximum sustainable yield $\left(\mathrm{F}_{\max }\right)$ was reported as lower than present fishing mortality, it has gave $\mathrm{Y} / \mathrm{R}$ that was higher than those obtained at both of $\mathrm{F}_{0.1}$ and $\mathrm{F}_{\text {pres. }}$. The $\mathrm{F}_{\max }$ as a reference point it is not a preferable in fisheries management and beyond the point $\left(\mathrm{F}_{\max }\right)$ overfishing occurs and the population collapses. So, the better one that used as biological reference points is $\mathrm{F}_{0.1}$, hence, the fisheries status of L. sceleratus in the Egyptian Mediterranean water reaches over exploitation level suggesting reduce it to $F_{0}$ 1 .

In conclusion, the phenomenon of lessepsian migration of puffer fish L. sceleratus to the Egyptian Mediterranean water reflect a good adaptation to new habitats that supported by a wide length range from smaller to larger individuals with seven age groups. In addition to an ideal condition factor with higher growth in length (than the same species from Red Sea where this species migrated from) is confirming an active physiological status to be adapted and established in the new habitats. In spite of, these species are prohibited by the Egyptian law as a commercial catch, the present findings showed high level of its exploitation of its stock explaining the illegal trade of this species in different markets regardless its poisonous effect. The importance of biological data of such species could emphasis the need of special management plan for conserve and better use of economically valuable fishery resources.

\section{References}

[1] D. Edelist, G. Rilov, D. Golani, J. T. Carlton, and E. Spanier, "Restructuring the Sea: profound shifts in the world's most invaded marine ecosystem" Diversity and Distributions, 1-9pp, 2012.

[2] A. Zenetos, S. Gofas, C. Morri, D. Rosso, D. Violanti, J. E. García Raso, M. E. Çinar, A. AlmogI-Labin, A.S. Ates, E. Azzurro, E. Ballesteros, C.N.Bianchi,, M. Bilecenoglu, M.C. Gambi, A. Giangrande, C. Gravili, O. Hyams-kaphzan, P.K. Karachle, S. Katsanevakis, L. Lipej, F. Mastrototaro, F. Mineur, , M. A Pancucci-Papadopoulou, A. Ramos Esplá, C.
Salas, G. San Martín, A. Sfriso, N. Streftaris, and M.Verlaque, "Alien species in the Mediterranean Sea by 2012. A contribution to the application of European Union's Marine Strategy Framework Directive (MSFD). Part 2. Introduction trends and pathways" Mediterranean Marine Science, 13:pp328-352, 2012.

[3] D. Golani, "Colonization of the Mediterranean by Red Sea fishes via the Suez Canal-Lessepsian migration. Pp. 145-188. In: Golani D., Appelbaum-Golani B. (eds.) Fish invasions of the Mediterranean Sea: Change and renewal. Pensoft, Sofia, 2010 .

[4] M. Oral, "Alien Fish Species in the Mediterranean - Black Sea Basin”. Journal of Black Sea/ Mediterranean Environment, 16 (1): pp 87-132, 2010.

[5] K. D. Simon, and A. G. Mazlan,"Length-Weight and Length-Length Relationships of Archer and Puffer Fish Species". The Open Fish Science Journal, 1:pp19-22, 2008.

[6] J. F. Gmelin, “Caroli a Linné, systema naturae”. Tom. I. Pars III. - pp. 1033-1516. Lipsiae. (Beer), 1789.

[7] M. M. Smith, and P. C. Heemstra, "Tetraodontidae. In: Smith MM, Heemstra PC (eds) Smiths' sea fishes” Springer-Verlag, Berlin, 894-903pp, 1986.

[8] J. L. May, and J. G. H. Maxwell, "Trawl fish from temperate waters of Australia". CSIRO Division of Fish. Res., Tasmania, 1986.

[9] H. Filiz, and M. Er, "Akdeniz'in Yeni Misafiri" (New guests in the Mediterranean Sea)" Deniz Magazin Dergisi, 3(68), pp 52-54, 2004.

[10] O. Akyol, V. Unal, T. Ceyhan, and M. Bilecenoglu, "First confirmed record of Lagocephalus sceleratus (Gmelin, 1789) in the Mediterranean” J. Fish Biology, 66: pp1183-1186, 2005.

[11] M. Bilecenoglu, M. Kaya, and S. Akalin, "Range expansion of silverstripe blaasop, Lagocephalus sceleratus (Gmelin, 1789), to the northern Aegean Sea" Aqua. Invas., 1 (4): 289-291, 2006.

[12] D. Golani, and Y. Levy, "New records and rare occurrences of fish species from the Mediterranean coast of Israel" Zoology of Middle East 36: 27-32pp, 2005.

[13] M. Corsini, P. Margies, G. Kondilatos, and P. S. Economidis, "Three new exotic fish records from the SE Aegean Greek waters" Scientia Marina, 70: pp319-323, 2006.

[14] S. Kalogirou, "Ecological characteristics of the invasive pufferfish Lagocephalus sceleratus (Gmelin, 1789) in Rhodes, Eastern Mediterranean Sea". A case study. Mediterranean Marine science, 14 (2): pp251-260., 2013.

[15] P. Kasapidis, P. Peristeraki, G. Tserpes, and A. Magoulas, "First record of the Lessepsian migrant Lagocephalus sceleratus (Gmelin 1789) (Osteichthyes: Tetraodontidae) in the Cretan Sea (Aegean, Greece)". Aquat. Invas., 2 (1): pp71-73, 2007.

[16] P. Carpentieri, S. Lelli, F. Colloca, C. Mohanna, V. Bartolino, S. Moubayed. and G. D. Ardizzone, "Incidence of lessepsian migrants on landings of the artisanal fishery of south Lebanon" Mar. Biodiv. Records 2: e71, http://dx.doi.org/ 10.1017/S1755267209000645., 2009.

[17] P. Katikou, D.mailto:biotoxin@otenet.grGeorgantelis, N. Sinouris, A. Petsi, and T. Fotaras, "First report on toxicity assessment of the Lessepsian migrant pufferfish Lagocephalus 
sceleratus (Gmelin, 1789) from European waters (Aegean Sea, Greece)" Toxicon, 54 (1): pp50-55., 2009.

[18] G. Minos, T. Karidas, M. Corsini-Foka, and P.S. Economidis, "New data on the geographical distribution of the invasive Lagocephalus sceleratus (Gmelin, 1789) in North Aegean". In: Proceedings of the 14th Panhellenic Conference of Ichthyologists, 6-9 May 2010, Piraeus, Greece, pp 283-286, 2010 .

[19] I. Jribi, and M. N. Bradai, "First record of the Lessepsian migrant species Lagocephalus sceleratus (Gmelin, 1789) (Actinopterygii: Tetraodontidae) in the Central Mediterranean" Bioinvas. Rec., 1 (1):pp 49-52, 2012.

[20] A. El- Haweet, M. R. Fishar, Y. Geneid, and E. Abdel-Moula, "Assessment of fisheries and marine biodiversity of Sallum Gulf, Egypt” Inter. J. Envir. Scie. Engin. (IJESE), 1:pp 21-34, 2011.

[21] Y. Halim, and S. Rizkalla, "Aliens in Egyptian Mediterranean waters. A check-list of Erythrean fish with new records" Medit. Mari. Sci., 12: pp479-490, 2011.

[22] E. Azzurro, L. Castriota, M. Falautano, F. Giardina, F. Andaloro, " The silver-cheeked toadfish Lagocephalus sceleratus (Gmelin, 1789) reaches Italian waters". Journal of Applied Ichthyology, 30, pp1050-1052, 2014. http://dx.doi.org/10.1111/jai.12471.

[23] F. Tiralongo, D. Tibullo, "Lagocephalus sceleratus (Gmelin, 1789), (Pisces: Tetraodontidae) reaches the Italian Ionian Sea, pp 203-204. In: Kapiris et al. (2014) New Mediterranean Marine Biodiversity Records" Mediterranean Marine Science, 15(1),pp 198-212, 2014.

[24] J. D. Šprem, T. Dobroslavić, V. Kožul, A. Kuzman, J. Dulčić, "First record of Lagocephalus sceleratus in the Adriatic Sea (Croatian coast), a Lessepsian migrant. Cybium 38(2):pp 147148, 2014.

[25] A. Izquierdo-Muñoz, and D. Izquierdo-Gomez, "First record of Lagocephalus sceleratus (Gmelin, 1789) (Actinopterygii, Tetraodontidae) on the Mediterranean Spanish coast, pp 686687. In: Katsanevakis S et al. (2014), New Mediterranean Biodiversity Records (October, 2014)" Mediterranean Marine Science 15(3), pp675-695, 2014.

[26] M. H. Kara, E. Ben Lamine and P. Francour, "Range expansion of an invasive pufferfish, Lagocephalus sceleratus (Actinopterygii: Tetraodontidae), to the south-western Mediterranean" Actaichthyologica et piscatorial, 45 (1), pp 103-108, 2015. http://dx.doi.org/10.3750/AIP2014.45.1.13.

[27] A. Deidun, A. Fenech-Farrugia, L. Castriota, M. Falautano, E. Azzurro and F. Andaloro, "First record of the silver-cheeked toadfish Lagocephalus sceleratus (Gmelin, 1789) from Malta. BioInvasions Records, vol. 4 (2), pp139-142, 2015.

[28] M. Bariche, Y. Letourneur. and M. Harmelin-Vivien, "Temporal Fluctuations and settlement patterns of native and Lessepsian herbivorous fishes on the Lebanese coast (Eastern Mediterranean)" Envir. Biol. Fishes, 70, pp81-90, 2004.

[29] IUCN - ISSG, “Aliens” 27:pp1-30, 2008.

[30] M. M. Sabrah, A. A. El-Ganainy, and M. A. Zaky, "Biology and toxicity of the pufferfish Lagocephalus sceleratus (Gmelin, 1789) from the Gulf of Suez. Egyptian Journal of Aquatic Research, 32 (1):pp 283-279, 2006.

[31] E. D. Le-Cern, "The length-weight relationship and seasonal cycle in gonad weight and condition in perch Perca fluviatilis". J. Anim. Ecol., 20 (2), pp 201-219, 1951.

[32] G. W. Snedecor, "Statistical methods applied to experiments in agriculture and biology" The low state University Press, U. S. A., 534 pp, 1956.

[33] T. B. Bagenal, and F. W. Tesch, "Age and growth. In methods for the assessment of fish production in freshwaters (Ed. T.B. Bagenal) $3^{\text {rd }}$ ed. I. B. P. Handbook, Blackwell, Oxford, pp 93-130, 1878 .

[34] C. G. Bhattacharya, "A simple method of resolution of a distribution into Gaussian components". Biometrics, 23 (1): pp115-135, 1967.

[35] J. F. Gayanilo, P. Sparre, and D. Pauly, "The FAO-ICLARM Stock Assessment Tools (FiSAT)". FAO Computerized Information Series (Fisheries). Rome, FAO. , 8, 1997.

[36] E. Ford, "An account of the herring investigation counductive at Plymouth during the years from 1929-1933". J. Marine Biol., Ass. U. K., 19, pp 305-384, 1933.

[37] L. A. Walford, "A new graphic method of describing the growth of animals" Bulletin of Biology, 90 (2), pp141-147, 1946.

[38] D. Pauly, and J. L. Munro, "Once more on the comparison of growth in fish and invertebrates" International Center for Living Aquatic Resources Management (ICLARM), Fish byte, 2 (1): $21,1984$.

[39] D. Pauly, "Some simple methods for assessment of tropical fish stocks. FAO Fisheries Technical Paper, Rome, 52- 234, 1983.

[40] 1980 D. Pauly, "On the interrelationships between natural mortality, growth parameters and mean environmental temperature in 175 fish stocks". J. Cons. CIEM, 39 (3), pp175-192, 1980.

[41] M. A. Said, I. A. Gerges, I. A. Mayiza, M. A. Hussain, and A. A. Radwan, (2009): Investigation changes in the Atlantic waters Characteristics along the Egyptian Mediterranean Coast. OceanObs'09 Conference, 21-25 September 2009 - Venice, Italy, p 26, 2009.

[42] R. J. H. Beverton, and S. J. Holt, "On the dynamics of exploited fish population" U. K. Ministry of Agriculture of Fisheries Investment, Serial, 19:533p, 1957.

[43] W. E. Ricker, "Computation and interpretation of biological statistics of fish population". Bulletin Fisheries Research Bd. Canada, 119: 200p, 1975.

[44] R. J. H. Beverton, and S. J. Holt, A review of methods for estimating mortality rates in exploited fish populations, with special reference to sources of bias in catch sampling. Rapp. P.-v. Reun. CIEM, 140:pp 67-83., 1956.

[45] J. A. Gulland, "The fish resources of the oceans". Fishing News Books Ltd., England. 255p, 1971.

[46] J. A. Gulland, "Manual of methods for fish stock assessment. Part I. Fish population analysis". FAO Man. Fisheries science, 4, pp154, 1969.

[47] J. A. Gulland, and L. K. Borema, "Scientific advice on catch levels”. Fish. Bull., 71 (2):pp325-335, 1973.

[48] L. E. Cadima, "Fish stock assessment manual" FAO Fisheries Technical Paper. No. 303. Rome, FAO, 161pp, 2003. 
[49] Statistica, "Statsoft-Inc for Windows Release", U.S.A, 2007.

[50] P. Sparre, and S. C. Venema, “ Introduction to tropical fish stock assessment" Part I-manual, FAO Fisheries Technical paper, 306/1 Rev. 1. 1992.

[51] M. Aydin, "Growth, reproduction and diet of pufferfish (Lagocephalus sceleratus Gmelin, 1789) from Turkey's Mediterranean Sea coast" Turkish J. Fish. Aqua. Sci., 11: pp589-596., (2011).

[52] D. Edelist, "New length-weight relationships and $L_{\max }$ values for fishes from the Southeastern Mediterranean Sea" J. Applied Ichthyology, 30 (3): pp521-526, 2012.

[53] L. Boustany, S. EL Indary and M. Nader, "Biological characteristics of the Lessepsian pufferfish Lagocephalus sceleratus (Gmelin, 1789) off Lebanon". Cahiers de Biologie Marine, 56, pp137-142, 2015.

[54] M. M. S. Farrag, "Fisheries and Biological studies on Lessepsian pufferfish, Lagocephalus sceleratus (Gmelin, 1789) (Family: Tetraodontidae) in the Egyptian Mediterranean Waters" Ph.D, Thesis, Fac. Sci., Al-Azhar Univ., (Assuit), Egypt, 2014.

[55] W. Kimmerer, S. R. Avent, S. M. Bollens, F. Feyrer, F. L. Grimaldo, P.B. Moyle, M. Nobriga, and T. Visintainer, "Variability in Length-Weight Relationships used to estimate biomass of estuarine fish from survey data". Trans Am Fish Society, 134: pp481-495, 2005.

[56] M. Kulbicki, N. Guillemot and M. Amand, "A general approach to length-weight relationships for New Caledonian lagoon Fishes". Cybium, 29 (3): pp235-252, 2005.

[57] A. Başusta, N. Başusta, and E. I. Özer, "Length-Weight Relationship of Two Puffer Fishes, Lagocephalus sceleratus and Lagocephalus spadiceus, From Iskenderun Bay, Northeastern Mediterranean, Turkey" . Pakistan J. Zoology, 45(4): pp1047-1051, 2013.

[58] N. Michailidis, “ Study on the lessepsian migrant Lagocephalus sceleratus in Cyprus" East Med Subregional Technical Meeting on the Lessepsian migration and its Impact on Eastern Mediterranean Fishery, pp 74-87, 2010.

[59] K. F. Lagler, "Fresh water fishery biology". (W. M. C., Brown ed) Comp, Dubuque, Iowa, 421 pp, 1956.

[60] M.L. Harmelin-Vivien, R. A. Kaim-Malka, M. Ledoyer, and S. S. Jacob-A braham, "Food partitioning among scorpaenid fishes in Mediterranean Seagrass beds" J. Fish Biol., 43: pp715-734, 1989.

[61] D. Golani, "Impact of Red Sea fish migrants through the Suez Canal on the aquatic environment of the Eastern Mediterranean”. Bull. Of Yale Sch. Forest Envir. Studies, 103: pp375-387, 1998.

[62] G. Bernardi, D. Golani, and E. Azzurro, "The genetics of Lessepsian bioinvasions" Fish Invasions of the Mediterranean Sea, pp71-84, 2010.

[63] I. Maiyza, M. Said, and M. Kamel, "Sea Surface Temperature Anomalies in the South Eastern Mediterranean Sea. JKAU": Marine Science, 21 (1):pp151-159, 2010.

[64] A. H. Weatherly, "Growth and ecology of fish populations" Academic Press, London, 293pp, 1972.

[65] E. H. Chan, and H.C. Liew, "Characteristics of an exploited tropical shallow-water demersal fish community in Malaysia" The First Asian Fisheries Forum. Asian Fisheries Society, Manila, Philippines, pp349-351, 1986.

[66] R. J. Wootton, "Ecology of teleost fishes" Chapman. \& Hall Ltd. U.S.A. 404p, 1990.

[67] T. B. H. Soliman, “Efficiency and selectivity of fishing gears and methods in Lake Edku and their effects on the stock of fish populations" M.Sc. Thesis, Faculty of science, Al-Azhar University, 356 pp, 2005.

[68] J. A. Gulland, "Fish stock assessment": A manual of basic method. FAO/ Wiley series on Food \& Agriculture, 1: 223p, 1983.

[69] P. Sparre, and S. C. Venema, "Introduction to tropical fish stock assessment" Part I-manual, FAO Fisheries Technical paper, 306/1 Rev. 2. 1998. 